\title{
Democratic Model for \\ Village Economic Resource Management in Nglanggeran, Gunungkidul
}

\author{
Puthut Indroyono• \\ Hempri Suyatna ${ }^{\circ}$ \\ Awan Santosa ${ }^{\circ}$ \\ Istianto Ari Wibowo \\ Rindu Sanubari Mashita Firdaus ${ }^{\circ}$
}

\begin{abstract}
This article seeks to describe the results of the research with the topic of developing a model of governance of natural resources at the level of the rural communities involving community participation, both in terms of production, distribution aspects, and aspects of the control of the factors of production. By taking the case of the village Nglanggeran, it sought to create a model of governance "alternative" in the failure of the model of "state" and "market" in protecting people's socio-economic interests of the community from systemic poverty and the threat of sustainable ecological environment. The experience of developing governance of a natural democracy in this village is expected to illustrate the potential, problems and alternatives completion faced by communities in improving the welfare in a fair and equitable manner.
\end{abstract}

\section{Keyword:}

natural resources; governance; economic democracy.

\section{Introduction}

This paper describes the results of action-research on developing an incubator model of economic democracy in natural resource governance at the village level. This study is motivated by the absence of a model of economic democracy in natural resource governance at the village level that involves participation from its community or people, both in aspects of production, distribution, as well as aspects of the mastery of factors of production. This study took the case of youth/ youth group called Bukit Putra Mandiri, which received a concession for forest/mountain area management of 48 hectares in Nglanggeran village.

The study attempts to develop an "alternative" governance model based on applying the principles of economic democracy in an effort to protect the socio-economic interests of society from systemic poverty and the threat of ecological sustainability on an ongoing basis.

Many studies about economic democracy are conducted by national and international

\footnotetext{
- Center for Economic Democracy Studies, Universitas Gadjah Mada

Email: ekonomikerakyatan@ugm.ac.id
} 
economists with various meanings and characteristics (Douglas (1920), Carnoy (1980), Dahl (1985), Poole (1987), and Smith (2000). Douglas highlighted in his book about the history of the European economy in the $19^{\text {th }}$ century that existed. The economy system was made for men (people) and not the other way around,

\begin{abstract}
"Systems were made for men, and not men for systems, and the interest of man which is self-development is above all systems, whether theological, political or economic (1920, p. 6)."
\end{abstract}

Meanwhile, Carnoy highlighted the implementation of economic policy, especially in the structure of production that encourages a prosperity gap. Carnoy offered an alternative strategy to reform economic policy and its implementation, such as (1) the shift of investment control from corporate domination to the public; (2) the reconstruction of economic decision making through democratic, workerand worker/consumer-controlled production (1980, p. 3-4).

Dahl also offered the possibility of developing an alternative economic structure that would be able to strengthen equality in politics and democracy by reducing inequalities in an ownership system and control of firms in corporate capitalism $(1985$, p. 4). On the contrary, Smith highlighted the economic condition in the $21^{\text {th }}$ century. Smith stated that the condition was not different with the previous economy based on imperialism. Through financial, technological, and military power, allied imperial-centers-of-capital controls the present world, by the same methods and for the same reasons.

In Indonesia, Hatta tried to formulate economic democracy and put it into the constitution since 1930 (Article 33 of the 1945 Constitution). In the explanation article 33, it was stated clearly about economic democracy.
This terminology was developed by Indonesian economists with various terminology Mubyarto (2002), Swasono (1987), Arief (2002), and Baswir $(2005,2010)$. Mubyarto used "Ekonomi Pancasila" or Pancasila Economy as terminology that pictured a just economic system based on the spirit of Pancasila as the ideology of Indonesia.

Meanwhile, Swasono (1987), Arief (2002), offered economic democracy as a structure that was based on historical aspect and culture. Baswir $(2005,2010)$, together with Arief complemented previous concepts of economic democracy with a highlight on the high rate of debt that burdened the national economic system. Above all, however, there have been so many critics to those economists that the real implementation barely reflects its notion since so many people define economic democracy as only about the ownership by "wong cilik" (small-holder).

The 2009 Nobel laureate, Elinor Ostrom, has conducted an evaluation of the perspective that leads to natural resource policies and governance throughout history. The decadeslong observation of many studies containing cases, concepts, methods of analysis, and conclusions, shows the tendency for two extreme two-extracellular pendulums, the -state- and -market-.

According to her, these scholars simply based their study solely on classical economic theory while developing new theories to explain unsuitable phenomena in the dichotomous world. In fact, Ostrom continued, the human race on Earth has a complex motivational structure and is formed in different arrangements, private-for-profit, governmental, and community institutions. This is all done in an effort to perpetuate life on a broad scale to create productive, innovative, or even the reverse; including damaging or perverse results.

In such a situation, Ostrom rejects a conventional management policy that states that common property is always poorly 
managed and must be regulated through a centralized (state/government) power pattern or privatized. Based on a number of studies on the management of natural resources, lakes, forests, and water; it was concluded that the results were no better among others based on standard theories.

Mubyarto is just like Ostrom, who also always uses a transdisciplinary approach in his studies. He uses a similar point of view to understand the socio-economic problems and management of economic resources (Mubyarto, 2002). Although best known as an economist, but in his studies, he also uses the perspective in political science, sociology, and anthropology.

He says that there is a difference between the basic economic assumptions between neoclassical theory and institutional economics in the way of achieving efficiency and in achieving harmony. If neoclassical theory believes that efficiency can be achieved through competition, institutional theory suggests that efficiency can be achieved through competition and/or cooperation. It is also a means of achieving harmony or balance, and if new harmony is impossible, at least there is the order that is based on peace.

The idea of a "third way" that encourages "democratic encouragement pattern" as an alternative to market and state pattern that has been acknowledged as business as usual and has been widely growing in various parts of the world. Not only the theoretical concept, but also applied in the practical programs. Some are successful, and some others can be considered failures. The state-driven centralized model has been widely criticized for failure, as well as market-driven ones, and it led to new hope for a model of socio-economic system development based on collective participation in production and distribution.

Included in this case is the collective approach which has now become a new magnitudein investment. The Alaska Permanent Fund is one example of the success of legislation that put people's participation in production in the United States, especially Alaska (Hartzok, 2002). The practice of state/private monopoly/ oligopoly seems to be regarded as the source of the problem of social-economic, political, and environmental crisis crises. The themes of collective participation in production and distribution are also widely developed through themes of social-entrepreneurship and cooperative concepts (Ridley, 2011).

The case study is expected to provide an overview of the village governance process that involves the active participation of young people in the development of natural resource governance. This study would be useful as a guide along with the efforts to develop the implementation of a democratic economic system at the local level (village), interconnection and consolidation of social institutions, including efforts to stem the penetration of capitalism and dependence of rural economy by outsiders, replication model in other villages, and the development of the theory based on empirical studies.

\section{Methods}

This paper aims to describe the preparation of democratic models in the management of village's economic and natural resources. The study was conducted in 2009 and 2016, and specifically for the latter, there are additional themes related to environmental. There is the difference in the method between the two studies, namely the use of survey methods in previous studies to obtain baseline data using a structured questionnaire so that quantitative data analysis is possible and some of which are relevant to use in the writing of this paper. Meanwhile, in the 2016 study, the method mostly relies on qualitative method and focus group discussions to explore data related to various socio-economic institutions in the village.

This study uses Participatory Action Research (PAR) when data and information 
are collected through critical reflection that all happen together in the field. There is some process in this kind of research approaches such as early diagnosing, problem mapping, action planning, taking action, monitoring, and evaluation. The result of that research will be used as a material to specify the next strategy for the next research.

In the model making process, data and information are arranged with charts, pictures, or model description based on data analysis, secondary data, in-depth interview, and focus group discussion in general group particular interest group such as youth, woman, farmer, community leaders, etc.

\section{Results and Discussion}

\section{Nglanggeran Potential and Characteristics of Poverty}

Nglanggeran is a village in Patuk district, Gunungkidul regency of Yogyakarta Special
Province. The area is on the outskirts because it is on the outer side of the northwest of the center of the district capital, Wonosari. The village of $762,099 \mathrm{Ha}$ is adjacent to the north of Ngoro-Oro village, south of Putat, west of Salam, and east of Nglegi Village (Image 1).

Topographically it is located at an altitude of 200-700 meters above sea level, and therefore, belongs to a plateau with an average temperature of $29^{\prime} \mathrm{C}$. The natural conditions of limestone and not being able to store water in the soil cause the availability of water becomes a problem during the dry season. When the dry season arrives, and the water supply is exhausted, the public must buy water that can reach IDR 90,000 - IDR 100,000 per tank (USD 9 or 10 prices in 2009). The current conditions are somewhat different after the government builds a reservoir that is expected to meet the water needs of citizens (Awang et al., 2013)

The population according to the village monograph of 2015 is 2,680 inhabitants

Image 1.

Map of Nglanggeran

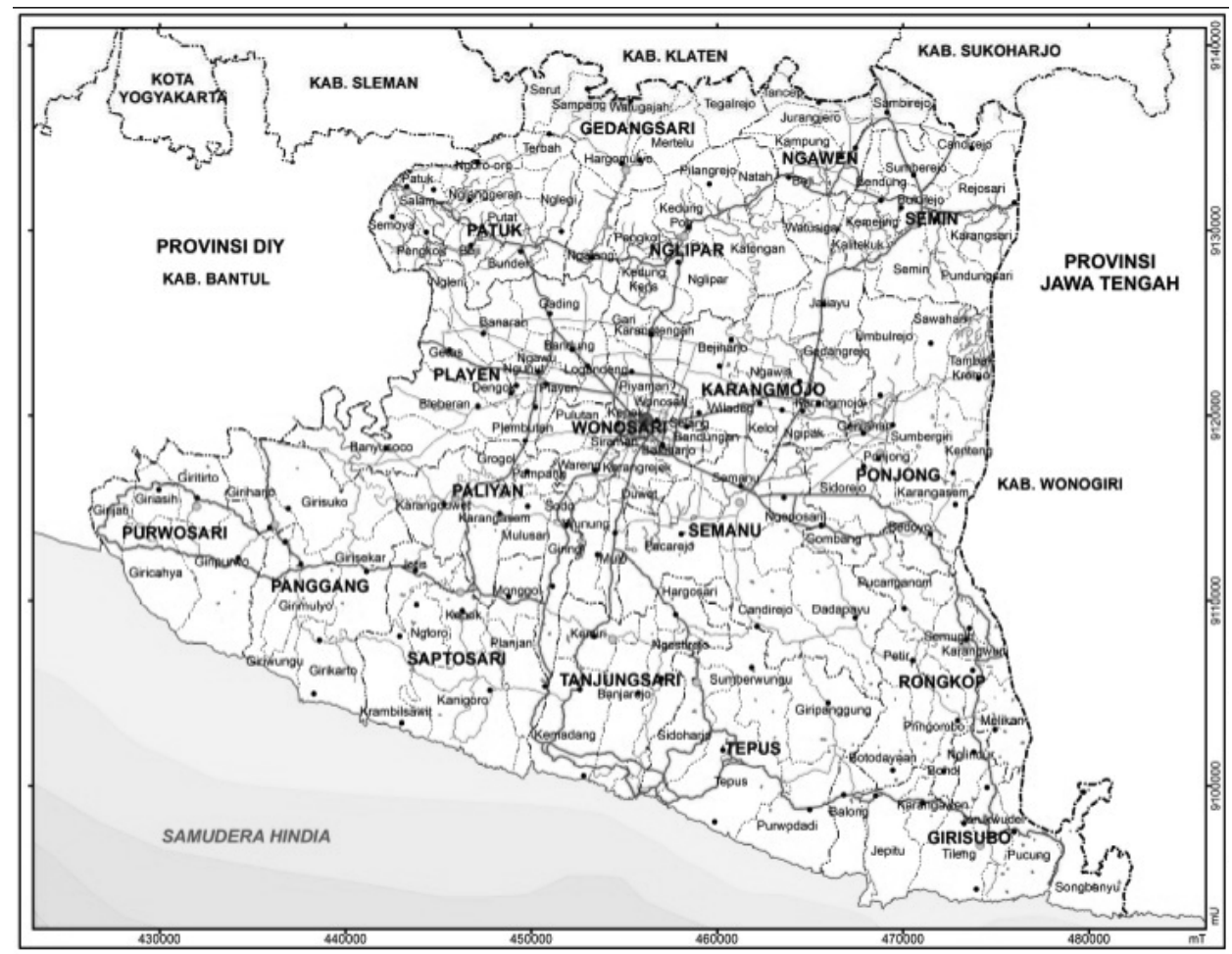

Source: http://www.gunungkidulkab.go.id/ 
Table 1.

Comparison of Livelihoods in Monograph 2015 and 2008

\begin{tabular}{|c|c|c|c|c|c|}
\hline \multicolumn{3}{|c|}{ Monograph of 2015} & \multicolumn{3}{|c|}{ Monograph of 2008} \\
\hline Category Type of Work & Number of people & $(\%)$ & Category Type of Work & Number of people & \\
\hline Civil Servant & 31 & 1.3 & Civil Servants & 75 & 4.4 \\
\hline Army / Police & 6 & 0.2 & Army/Police & 19 & 1.1 \\
\hline Peasant & 7 & 0.3 & Peasant & 678 & 39.5 \\
\hline Farmers & 841 & 35.4 & Farmers & 678 & 39.5 \\
\hline \multirow[t]{2}{*}{ Breeder } & 11 & 0.5 & & & \\
\hline & & & Farmer Laborer & 51 & 3.0 \\
\hline \multirow[t]{2}{*}{ Entrepreneur (Trader) } & 173 & 7.3 & Entrepreneur (Trader) & 11 & 0.6 \\
\hline & & & Merchants & 18 & 1.0 \\
\hline Private employees & 222 & 9.3 & Labor industry & 10 & 0.6 \\
\hline Builders & 65 & 2.7 & Construction workers & 125 & 7.3 \\
\hline Craftsmen & 2 & 0.1 & Craftsmen & 15 & 0.9 \\
\hline \multirow[t]{2}{*}{ Art Workers } & 4 & 0.2 & & & \\
\hline & & & Transportation & 15 & 0.9 \\
\hline Retired & 9 & 0.4 & Retired & 22 & 1.3 \\
\hline Service & 231 & 9.7 & & & \\
\hline Others & 523 & 22.0 & & & \\
\hline Unemployed & 251 & 10.6 & & & \\
\hline Amount & 2,376 & 100.0 & & 1,717 & 100.0 \\
\hline Total population & 2,680 & & & 2,726 & \\
\hline
\end{tabular}

Source: Village government, 2008, 2015, processed

(males 1,340; 1,340 females). This number has decreased compared to the year 2008, which at that time was as many as 2,726 inhabitants. This population decline is closely related to urbanization whose objectives are among others to obtain a better livelihood. A young villager said it was difficult to get young men and women together to develop the potential of their village. In general, children who have graduated in the village will continue their education to a higher level in the city and after graduation will find work elsewhere.

Some of the occupation based on farming, such as farmer and peasant have been considered as a low prospect to prosperity, especially in the eyes of the youth. The same thing goes for the agricultural sector today. That is also considered less promising to improve the welfare. It is interesting to compare labor force and livelihood data in both years (Table 1).

If the percentage who cultivate agriculture in 2008 is recorded as 1,407 people from the entire workforce, consisting of 678 farmers, 678 farmers and 51 peasants, by 2015 the number of farmers was only 841 people, laborers, farmers were 7 people. In 2015, in terms of a number, the farmers show a number greater than the number in 2008, but when added to the number of farmhands, then this number has decreased.

If in 2008 the number of people engaged in agriculture numbered 1,407 people (landowners, farmers, farm workers), then in 2015 the number is only 848 people or is decreased by $40 \%$. The pressure on the inability of the agricultural sector in the country to meet the needs of income for those who depend on this sector is forcing them to change their profession to other sectors, including migrating to find work outside the village. At first glance, it can be seen from the category of livelihood that is not listed in village monography in 2008, but appears in the monograph of 2015, i.e., farmers, builders, art workers, private employees, and unemployed.

The farms cultivated by residents are mostly dryland farming. Although water 
is a rare commodity, rice fields remain an important commodity for the community. The area of rice planting is $27.34 \mathrm{Ha}$ with one-year planting period during the rainy season. Other commodities cultivated are "palawija" (crops) including corn, cassava, peanuts, and soybeans. There are also important fruits produced, i.e., rambutan, bananas, and durian.

Plantation crops such as cloves and chocolate also sought by some residents, although there is not much volume. By looking at villages located in the area and having forests, both community forests and state forests, the results that are "mainstay" are wood, such as teak, acacia wood, sandalwood, and mahogany. Wood products from the village are currently used as industrial raw materials outside the village, including in the neighboring village of Putat.

The number of poor people in Nglanggeran registered in the rice recipient's list for the poor (raskin-rice for poor) is 300 households spread in 5 hamlets, from 700 households or $42.8 \%$. There is an interesting recognition of the poor families who responded to the survey. When they were asked to show their family's position in the community, if it divided into five categories of prosperous groups. The first group is the most prosperous, the second of prosperous groups, the third of moderate groups, while the fourth and fifth of each group are less prosperous and least prosperous.

At the time of the previous study (2009) (Awang et al., 2013), Nglanggeran village is the choice of location recommendation result after discussion with the local government. It was chosen because it is considered a poor village, although not the poorest. Preliminary observation, indicated that poverty is not as severe as imagined. This is evident from the results of the welfare survey, which shows the difference between the perceptions of "poor people" and perceptions by policymakers characterized by the allocation of "poor rice."
According to them, poor rice is quite helpful, but many of them actually do not need it.

Poverty is very diverse, ranging from the inability of individuals to meet basic needs of life to a wider understanding by including social and moral components. Natural poverty, which is the state of poverty caused by natural limitations, both in terms of human resources and natural resources. Nglanggeran village's geographical location is located in the barren mountains and does not get support by enough water availability, so experiences drought.

Cultural poverty, is poverty caused by cultural factors, which causes the process of poverty preservation in the community. In addition to these two definitions, there is also a type of poverty caused by factors of injustice in the ownership of factors of production. Poverty in this sense is better understood as a systemic condition known as structural poverty (PSEK, 2009).

In recent debates, poverty is also understood not just objectively oriented (referring to local poverty indicators) but also subjective-oriented (how poor people understand the poverty). Subjectively, people make judgments about poverty based on the preferences of social values and their culture. With this preference, they set up a measure of well-being with local values.

Damanik's research (2014) states that the weight of subjective well-being is more severe regarding the non-material aspects than the material aspect. The preference of emotional satisfaction (family harmony, social relationships, security) in the assessment of life satisfaction levels shows the strong role of this non-material aspect in the formation of subjective well-being.

In many ways, the objective of poverty is often not in line with the subjective poverty. When referring to poverty data, many people fall into the category of poverty, but often the person does not consider himself a poor person. For them, prosperity is enough as interpreted 
by living with a calm, comfortable and peaceful attitude.

An interesting finding in the survey was the recognition of poor families when they were asked to assess themselves and put themselves into the five poor categories. The first group is the most prosperous, the prosperous in the second group, the third group being medium, while the fourth and fifth groups are each the less prosperous and the least prosperous. It should be pointed out here that all respondents are on the list of names in local government records as poor and get rations of raskin.

Table 2.

The Perception of the Poor About Welfare

\begin{tabular}{lcc}
\hline \multicolumn{1}{c}{ Welfare position } & Respondents & \% \\
\hline Group 1 Most Prosperous & 0 & 0.0 \\
Group 2 Prosperous & 2 & 4.3 \\
Group 3 Medium & 10 & 21.3 \\
Group 4 Less Prosperous & 12 & 25.5 \\
Group 5 At least prosperous & 23 & 48.9 \\
\hline & 47 & 100.0 \\
\hline
\end{tabular}

Source: Pengembangan Model Desa Inkubator Ekonomi Kerakyatan (Awang et al., 2013)

The $4.3 \%$ stated that they were in the second group meaning they were in the prosperous group and $21.3 \%$ were in the medium group. Furthermore, $25.5 \%$ admitted to being in a less prosperous group and $48.9 \%$ in the least prosperous group. If the last two groups can be classified as poor families, then it can be concluded that all the poor people, which are really poor are $48.9 \%$ and $25.5 \%$ or $74.4 \%$.

Associated with the number of poor people who were then subjected to government policies to receive raskin assistance and direct cash assistance (BLT), this amounted to 300 families from 700 families or $42.8 \%$. So, if group five-persons is used as the size of a family that is really poor and needs compensation (Raskin and BLT), then only $48.9 \%$ of 300 families or as many as 147 families need to get it. While the poor $(25.5 \%)$ do not need compensation, they need other, more constructive, poverty reduction programs.

The elaboration would make more sense when $58 \%$ of the poor are those who are in the productive-age between $20-50$ years, $4 \%$ are under 30 years old, $28 \%$ are $30-40$ years old, and $26 \%$ are $40-50 \%$. Productive programs that provide employment and entrepreneurial programs will certainly be more beneficial to the poor who are still at a productive age.

If associated with poverty due to injustice in the mastery of factors of production, it can be seen from their high dependency individually and collectively. The survey shows that villagers' land ownership pattern is as follows: $89 \%$ of the population owns less than $0.5 \mathrm{ha}$, consisting of $21 \%$ land between $1,000-20,00 \mathrm{~m}$, $21 \%$ between $2,000-5,000 \mathrm{~m}$, and $47 \%$ have land less than $1,000 \mathrm{~m}^{2}$. Hostile natural conditions, and dependence on agricultural inputs such things as seeds, fertilizers, and pesticides from the outside have actually been realized and have strived settlement with the cropping system and increased the use of local inputs. This proved to be little help in reducing that dependency.

Unfortunately, the production output produced is still sold in raw materials. This condition in general causes economic value added (rent) and is not much to be enjoyed by them as producers, but more enjoyed by the linking link between producers and consumers. This situation can be described as "producers, they get the lowest selling price, on the contrary, as consumers get the highest price."

Performance in an economic sector that reflects access to the mastery of production factors is also determined by access to distribution or marketing networks. In this case, only a small number of producers are self-marketed or brought directly to the market for sale $(11 \%)$. There are several possibilities, Firstly, the characteristics and volume of production are small so the transportation costs are high. Secondly, the middlemen who 
have the means of transport bring agricultural products to market. Third, the short-term need for cash money causes producer farmers to be unable to "hold goods until the price is good." Fourth, the inability to increase the added value of products produced, and others.

The family income pattern, according to the survey, is mostly contributed by working outside the agricultural sector (35\%) while agriculture is only $30 \%$. Family expenditure pattern is as much as $77 \%$ allocated for the fulfillment of food needs. The remaining $23 \%$ is divided into non-food routine expenditures by $6 \%, 12 \%$ children's education, $3 \%$ health, and social and other by $1 \%$.

It can be concluded that this condition indicates incoming capital (cash inflow) are not able to hold to move the production of the local economy. Another interesting finding is the relative availability of capital in the community (in formal and informal institutions) but is more widely used to meet consumption needs than production.

Based on the findings, it is concluded that poverty in Nglanggeran is caused by structural poverty factors. The uneven land ownership affects low scale production and income. The narrowness of average land tenure, access, and control of production inputs include capital (material capital and intellectual capital) is also low. In the distribution aspect, since $90 \%$ of farmers do not sell their own crops as a result of heavy costs, the opportunity to access additional value must be "relinquished" to other parties who have direct access to the market/consumer. In the aspect of public consumption, the dependence on external products including food and non-food, is a problem especially if it can be independently produced.

The problem of poverty of the villagers cannot only be inferred from the data above, but it should be placed in a pattern of relations with economic actors who have earned "profit" from the additional value of production and distribution. Poverty really does not have to exist if the democratic economic system is run well because the economic system will work automatically to eliminate it through patterns of production, distribution, and consumption democratically. The national economic system that puts the village and its people only as the object of development has been structurally displaced the existing family kinship system and replaced it with a liberal/neoliberal economic system (Awang et al, 2013).

\section{Democratic Economic Dimension}

Different types of poverty must be looked at for a different solution. Structural poverty eradication should also be addressed through a structural approach as well. The approach is to tackle poverty as a result of the economic system characterized by the "exploitation" relationship pattern. The concept and model of economic democracy developed as part of poverty reduction efforts.

There are at least three basic principles of the substance of economic democracy (Baswir, 2010), which is relevant and applicable in a particular area, in this case, is the village. Firstly, the "production democracy," a condition that ensures the participation of all members of society in the process of product formation.

This is in line with the sound of Article 27 of the 1945 Constitution which states, "Every citizen is entitled to decent work and livelihood for humanity." Some indications that can be used to identify the conditions in the village based on the dimensions of production is by the number of unemployed productive age workers, the average land tenure, access to financial capital, and access to production knowledge (training, cooperative production, and others).

Secondly, the "allocation democracy," a condition which gives the opportunity for all members of society to enjoy the products of production. This understanding is not only limited to the fact that the poor can obtain social 
security, but also concerns the participation of the community in enjoying the added value of produced production.

For example, farmers cannot get enough added value in the production process they are in. Some indications that can be used in viewing this dimension include access to education and health population; Availability of consumer goods in the village of good food, clothing, and boards; The existence of cooperation between village businesses; the existence of consumption cooperatives and/or marketing cooperatives; the number of people involved in the pattern of exchange of goods and services in the village; and others.

Thirdly, the control over the economic system (production system and allocation). Everything that happens in society must always be controlled by the members. Society is not a "spectator," but a subject in the economic activity.

Indicators that can be recognized in this dimension include community involvement in the planning and implementation of APBDes (Village Budgeting); community access to strategic village resources such as water, forests, and other natural resources; access to affordable production and capital facilities in the village; existence of collectively managed natural and economic resources; existence of cooperatives capable of providing the needs of consumption and supply of raw materials, capital, technology, and skill improvement on the village scale. The description of the villagers' problems, as identified in previous research, can be summarized in Table 3 .

\section{Application of Economic Democracy Model}

Based on the reality in the field, the model and scenario of economic democracy incubator in such cases are strongly influenced by the complexity and fragmentation between elements and business sectors of society. However, the democratic model seeks to reverse the pattern of "exploiting" relationships through the principles of community-

Table 3.

Production, Consumption, Distribution, and Institutional Issues

\begin{tabular}{|c|c|}
\hline Problem & Problem Details \\
\hline Production & 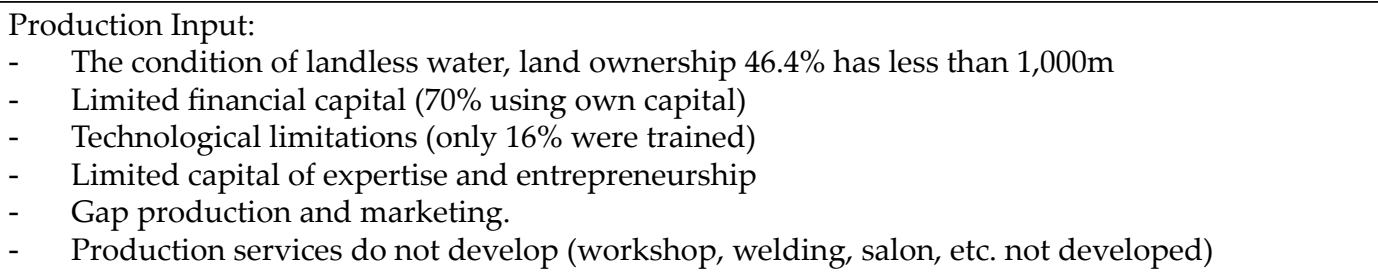 \\
\hline Consumption & $\begin{array}{l}\text { Food consumption: } \\
\text { - Only focus on meeting the needs of carbohydrates, underdeveloped farms, the needs of meat } \\
\text { and eggs from outside the village, the needs for vegetables } \\
\text { Non-food consumption: } \\
\text { - } \quad \text { Dependence from the outside. } 5 \text { people and } 50 \text { individually-run stalls are the main sources. }\end{array}$ \\
\hline $\begin{array}{l}\text { Distribution/ } \\
\text { Marketing }\end{array}$ & $\begin{array}{l}\text { Establish a distribution / marketing structure that does not benefit most of the population. } \\
\text { "Purchased at a price as expensive as possible, selling at low prices." This is because: } \\
\text { - } \quad \text { Characteristics and volume of production is relatively small, cost of transport is expensive } \\
\text { - } \quad \text { Dependence on middlemen ( } 52.8 \% \text { ) who have access to the market } \\
\text { - } \quad \text { Short-term needs force them to have no bargaining power } \\
\text { - } \quad \text { Fairness of the price ( } 52.8 \text { say not fair), but have no other alternative }\end{array}$ \\
\hline Institutional & $\begin{array}{l}\text { - Groups (savings and loans, PKK, youth groups, farmers' groups / livestock) have not been able } \\
\text { to develop activities for the creation of goods and services to meet the needs of both production, } \\
\text { consumption, and distribution. } \\
\text { - Community groups have not been able to independently or collaborate between groups, } \\
\text { contributing to the holding of "economic rent" to prevent the flow of funds outside the village. }\end{array}$ \\
\hline
\end{tabular}

Source: Awang et al., 2013 
community cooperation, in order to have and be able to increase "bargaining power" in production, consumption, distribution, through institutional development in society. Operationally elements developed in this model are:

\section{Farming Cooperative (Ekora Farming)}

This cooperative compiles farmers' groups that are mostly fathers and are present in every hamlet and other socio-economic support institutions, such as the Savings and Loan Economic Village (UED-SP). The cooperative is engaged in the cultivation of agriculture, livestock, plantation, and forestry, with the concept of integrated agriculture (integrated farming) and organic-based. There are some potential commodities in Nglanggeran Village such as rice, corn, cassava, wood, fruit, and livestock cultivation such as cow and goat. This farming cooperative has the certain vision to increase collective bargaining power in an effort to encourage productive activities and overcome some possible difficulties that might come in the process of business development.

The existence of cooperatives can prevent the flow of funds out of the village, so then it can be spent on cooperatives owned by citizens. Therefore, the way that can be taken is to collect farmer groups so that its members will join to become active members.

\section{Women's Cooperative (Ekora Trading \& Microfinance)}

Just as the farmer cooperatives, women's cooperatives development vision is to raise mothers who had been active in the association, women group, and Dasawisma (ten household group) on each RT (Rukun Tetangga - about 4050 households / Hamlet.

Cooperative is expected to answer the problem in the field of processing and marketing. The pattern of cooperation needs to be created to process the many available raw materials in the village (cassava, banana, rambutan, coconut, cacao, etc.) and aims to fulfill market segments within the village such as schools, meetings and stalls, and also outside the village (market and order).

In addition, to meet the various needs of public consumption, this effort is also to erode piecemeal dependence of consumer goods from outside the village. The cooperative is expected initially - but not limited to, be able to manage members' savings and loan funds and other rolling funds in the village as a source of microfinance for cooperatives and members.

\section{Youth Cooperative (Ekora Tourism)}

This cooperative will bring together village youth who have been active in Karang Taruna activities. The cooperative will specifically develop the Nglanggeran Mountain ecotourism with the support of the availability of locally processed food products (cocoa and corn) and handicraft products made from wood which are widely available in Nglanggeran Village.

The three cooperatives will be connected on the basis of the development of the center of economic democracy (Sentra Ekora). Sentra Ekora will be a representation, interconnection medium, and melting-pot for the three cooperatives above. It will be realized through a "physical building" owned and managed jointly by all three cooperatives with appointed managers from their third representatives.

At least four business units (services) that can be developed are trading-house, savingloan unit, promotion unit, and training center. More clearly the incubator model of economic democracy offered can be seen in Table 2.

It describes the socio-economic conditions of the village both in 2009 and 2016. Those conditions are implied from the monographic comparisons (2008 and 2015), the same recipients of raskin/BLT, youth unemployment, and problems such as agriculture, low ownership of factors of production, and others. The answer is there 
Image 2.

Incubator Model of Nglanggeran Village Economic Democracy, 2009

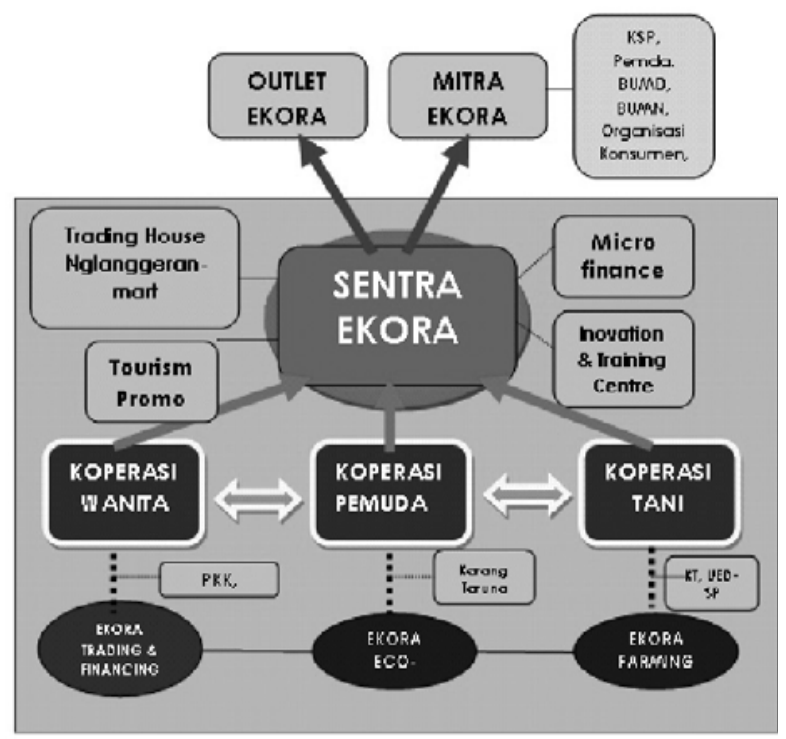

Source: Awang et al., 2013

have been no significant changes in terms of social transformation especially related to poverty problems in more than five years. This is all due to the structural factors or injustice that was described earlier as structural poverty

The description also illustrates the issues of economic democracy covering of production, consumption, distribution/marketing, and institutional issues. Finally, to overcome these above problems requires a "road" of economic democracy. The road model is offers three elements, namely farming ecosystem by farm cooperatives, eco-trading and microfinance by female cooperatives, and youth eco-tourism.

\section{Institutionalization of Bargaining Power}

The conditions in 2016 were different from 2009 when the first study was conducted. The current discussion may be regarded as a "model test" to what extent the picture of economic democracy develops in the village. Economic democracy as one of the main objectives that increases the collective bargaining power of the people will be able to be applied, especially through institutional governance, played by the youth element in the governance of economic resources.

The socio-economic condition of Nglanggeran village at the time of the research has shown the difference. At least this time the predicate of poor villages is rarely attached to the village, among others because now the village is known as one of the favorite places in Gunungkidul. If at the time of the previous study, the number of tourist visits per year only as many as 2,400 people, in 2015 the number of tourist arrivals (domestic and foreign) reached 255,000 people. It captures the influence of economic democracy implementation to the economic development in the village.

Table 4.

Tourists in Nglanggeran, 2007 - 2015

\begin{tabular}{ccccc}
\hline \multirow{2}{*}{ Year } & \multicolumn{2}{c}{ Tourists } & Total & $\begin{array}{c}\text { Ups/down } \\
\text { nom }\end{array}$ \\
\cline { 2 - 3 } & Domestic & Foreign & & \\
2007 & 1,437 & 13 & 1,450 & \\
2008 & 1,521 & 15 & 1,536 & 5.9 \\
2009 & 2,335 & 65 & 2,400 & 55.9 \\
2010 & 7,314 & 132 & 7,446 & 210.3 \\
2011 & 18,209 & 134 & 18,343 & 146.3 \\
2012 & 27,675 & 200 & 27,875 & 52.0 \\
2013 & 85,424 & 234 & 85,658 & 207.3 \\
2014 & 325,827 & 476 & 325,303 & 279.8 \\
2015 & 255,388 & 529 & 255,917 & -21.3 \\
\hline
\end{tabular}

Source: Pokdarwis Nglanggeran

Another interesting development is also shown by the increase of financial turnover from 2012 to 2015, 81.2 million to IDR 424.7 million in 2013, IDR 1,422.9 million in 2014, and IDR 1,542 million in 2015 or the increased average of $449.7 \%$ per year. With the revenue, the management is able to contribute to the village's income (PADes) which increased during the last 4 years (2012-2015). Similarly, Nglanggeran is also able to record levies to the region of IDR 196.4 million in 2014, and IDR 369.2 million in 2015.

Currently, products and services offered collectively owned by local peoples to tourists have also been much improved compared to six years ago. Some of them are (1) Nature 
attraction that consists of ancient volcanoes and beautiful scenery and agricultural leisure such as rice fields in the village.

In 2016 the attraction was also supported by the development of bombing (mini reservoir) on 0.34 ha which functioning as a source of irrigation of 20 ha of fruit gardens, as well as become a place with beautiful scenery; (2) Tradition and culture of the community are also packaged by the management to attract the tourists such as resultant customs, jathilan dance, and traditional ceremonies of society.

The event is held regularly so it can also add to the community's intimacy, foster communal culture (gotong-royong), hospitality, and harmony, and the potential of other art and cultural traditions to stay awake. (3) Tourists can directly watch the making of masks and bracelets, as well as they can learn to make them. This learning package is much in demand by foreign and local tourists especially from among students. (4) In terms of local food, dodol cocoa and cassava brownis become the mainstay; even currently being built "Rumah Coklat" (House of Chocolate) by the manager to become an outlet for local products especially cocoa; (5) In addition to Nglanggeran mountain climbing route, the attraction of artificial rides is also developed such as outbound games, flying fox, natural education package (farming, cocoa cultivation, environmental love package). Last but not least, in some places there is also a place provided for tourists to take pictures themselves of the visitors (selfie).

Physical facilities offered to tourists has also increased. For those who want to live and enjoy the daily life of the Nglanggeran villagers, currently, the community co-managers provide a homestay vacation option. Homestay is used to occupy the homes of residents who have prepared to accommodate tourists who stay for a vacation. Now there are 80 homestay

Image 3.

Homestay Map, 2016

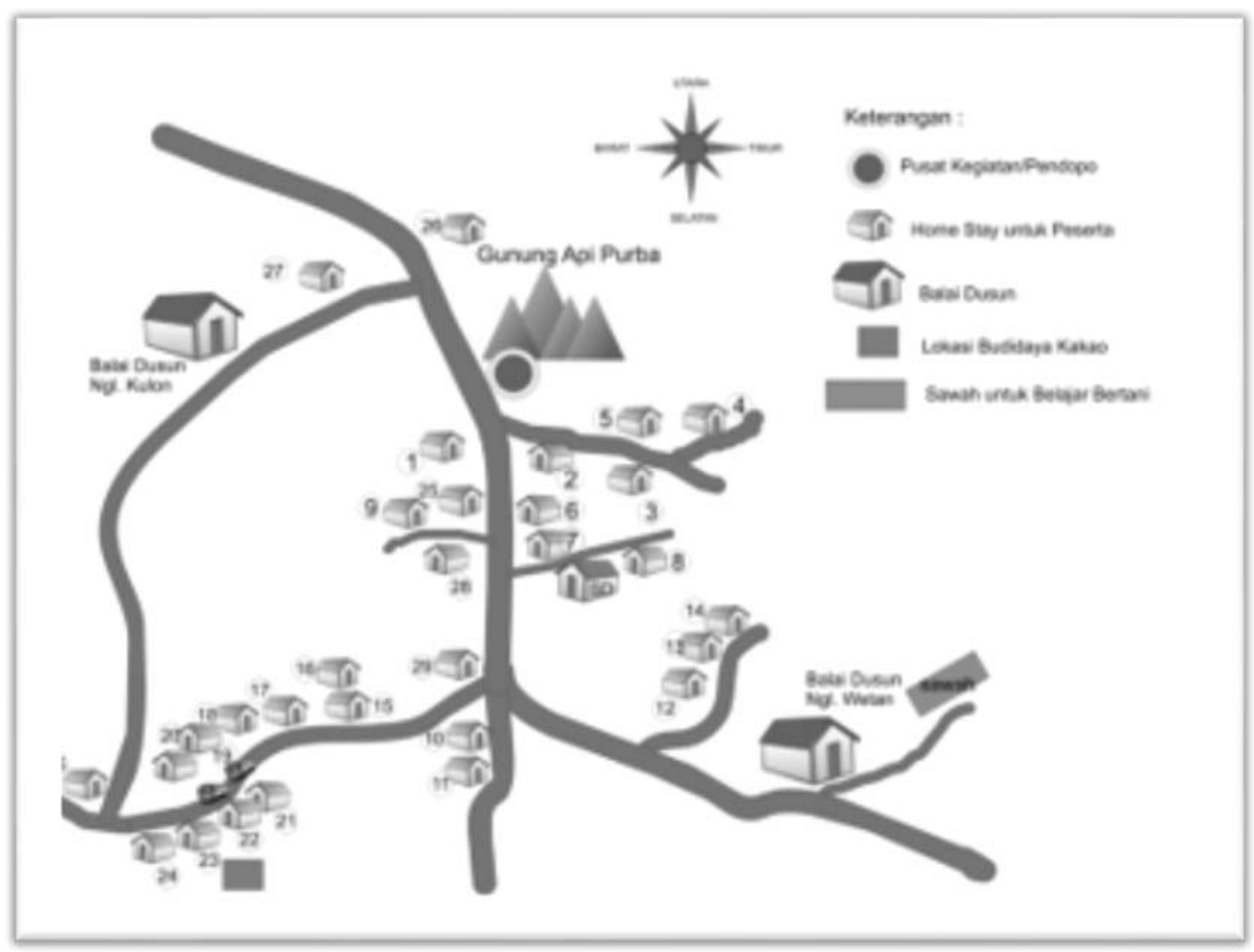

Source: Pokdarwis, Nglanggeran 
homes, which can accommodate 280 visitors to stay in them.

From the above description, it can be concluded that the process of economic democratization has been developed in Nglanggeran village through a governance model that involves the community. This is indicated by the central role of managers who are able to integrate elements of the potential economic resources in the village. Institutionally, at least the economic structure of the economic resource management that influences the ecotourism governance process includes (1) The youth of the core management totals 14 people, serving as the main operator covering the management of nature tourism (ancient volcano, small dam or embung); (2) The "Purbarasa" group, consisting of mothers numbering about 55 people, who produce processed foods mainly chocolate, culinary, including "how to cultivate" learning packages; (3) Kumpul Makaryo's farmer group of 100 people involved in the management of the area, especially agriculture-related; (4) Homestay owners' group. At this time, they number 80 houses, which provides a place to stay for tourists who want to enjoy the daily life of the countryside, as well as travel. The total homestay capacity is 280 people.

How the decision-making mechanism in ecotourism governance cases is done, whether done in democratic ways by considering the aspirations of the people, or otherwise is only decided by a small group of elites. In the incubator model of economic democracy's term how the control is over the economic system, people can participate in production and its result. Based on the results of the indepth discussion with the management, we obtained the picture that the highest decision

Image 4.

Incubator Model of Nglanggeran Village Economic Democracy, 2016

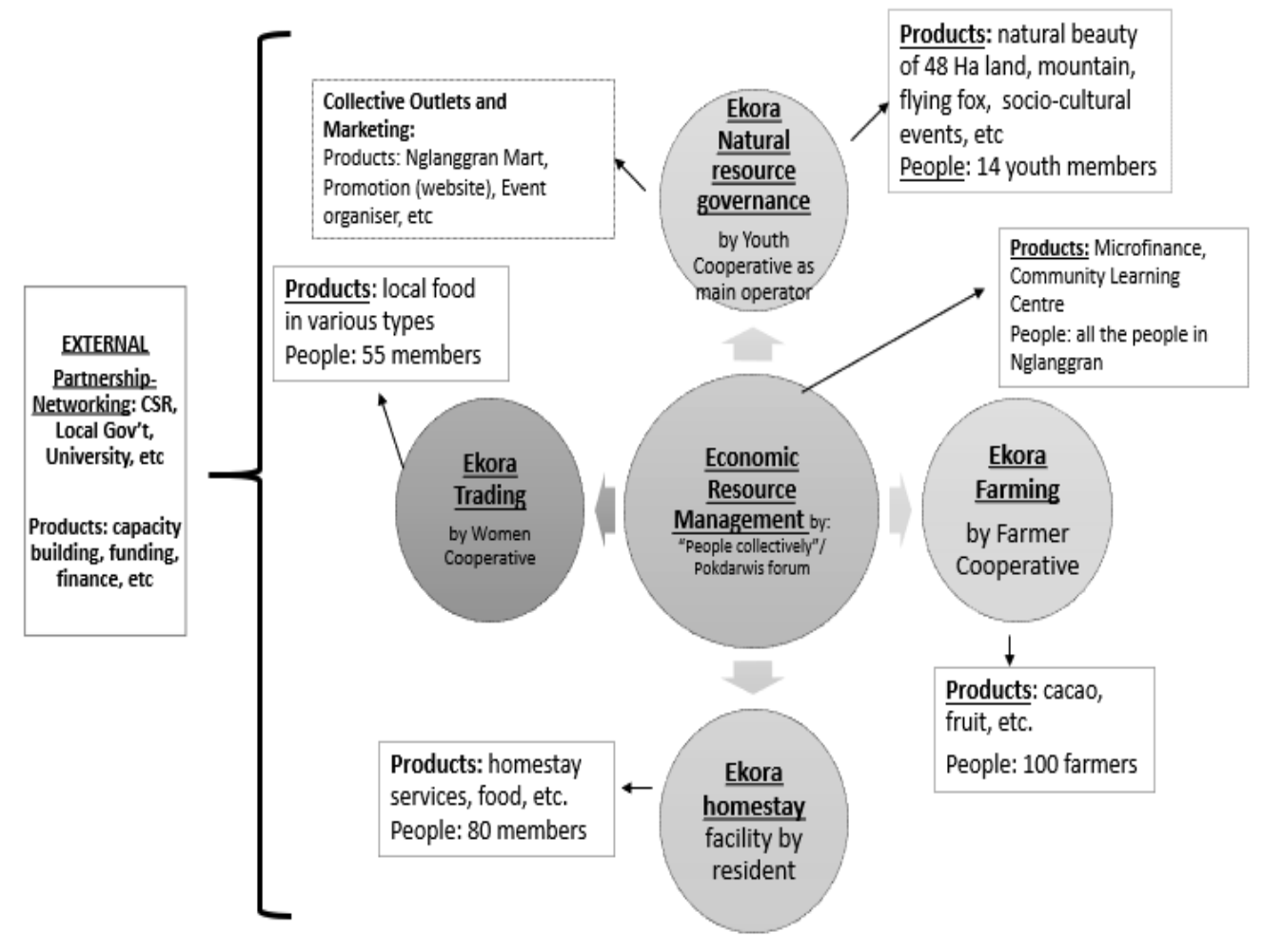

Source: Research Report 2016, processed 
regarding the management of tourism is in a pokdarwis (tourism awareness group) forum, whose membership comes from elements of youth, village government, community leaders, farmer groups, women groups, homestay owners, and traders. The youth would be the main or driving force of the socio-economics related to ecotourism in the village.

Beside the Pokdarwis forum as a model of economic resource management collectively and as an element of the collective decision model democratically in Image 4, there are four other elements that encourage production patterns and allocations driven by the people (compared with Image 2, which has three elements). The other four elements are Ekora's Farming, Ekora's Trading, Ekora's Homestay, and Ekora's Natural Resource.

Theoretically, the interconnection between them has increased the bargaining positions of the people in the production product and services in the village. Ekora trading can be a driver for shifting patterns, as what was originally only sold as raw materials can now be processed into processed food products. This can indirectly increase the bargaining power of farmers. Although in the interviews revealed that the production volume of processed food is still relatively small.

Second, Ekora's trading collectively can help the process of developing the village industry, especially in the case of processed food industries that are made using local raw materials and handicrafts. While the third Ekora's homestay is a form of service industry development in the village that has a great impact on the income of the owner's family and in the creation of employment. The democratic mechanisms in the management of homestay that distinguish the "market" mechanism can be seen from the role of management/operator in placing guests who want to stay in the village. They have to go through the operator who will direct the guest to a particular homestay; the guest cannot choose by himself. Similarly, the rules of the game are agreed upon by the homestay owners.

Finally, Ekora's Natural Resource is a manifestation of the Constitution of article 33, paragraph 3, in the village's case, that: "The land, the waters and the natural resources within shall be under the powers of the State and shall be used to the greatest benefit of the people."

This road of economic democracy in Nglanggeran can be distinguished with neoliberal patterns or market mechanisms when those with access are those with large capital. Investment, in this case, can be made by the people through the development of homestay services. With such a pattern, in addition to the people can participate in the production, as well as in the allocation mechanism.

This research may need to be followed up with further research to see the development of economic democracy and its effects on poverty alleviation, especially structural ones. It needs a further test, but the pattern of change that occurred during the last six years shows a pattern based on the principles of economic democracy. There are not many tourism destinations that apply the pattern of economic democracy in Gunungkidul district, as well as in the Special Region of Yogyakarta.

\section{Conclusion}

Lately, many people are talking about the concept of "building from the periphery," which often still has many weaknesses perspectives and practice ranging from a topdown approach, ego-sectoral, unsustainable program and so on (Hamid, 2003). Many understand that the "outskirt" is meant in terms of physical or material.

In such a perspective, the subject only leads to "rural-urban," "java-outer Java," "regional-center" themes that lead to the inaccessibility of infrastructure (physical) on the villages. "Pinggir" or periphery always considers poor facilities and infrastructure, 
technology, capital, so it takes the program flushing from the center to the periphery.

If this process of developing periphery does not involve community participation that based on socio-economic, institutional integration that exists in society from the very first place, then it is the market mechanism that works. This has resulted in the marginalization of society from the periphery.

The result of the study in Nglanggeran village shows that this model of democracybased natural resource management can run well. Community participation and support in the form of developing its collective capacity or bargaining power to face of the "destructive power" of market forces are key to the success of ecotourism development in Nglanggeran Village.

Integrated eco-tourism management model of tourism attraction management, institutional strengthening, environmental management, utilization of local sociocultural values, and the optimization of various natural resource potentials in the community are keys to success. Issuance of Decree granting "concessions" forest management/Nglanggeran Ancient Mountain, is a form of allocation mechanism in the system of economic democracy, and therefore can serve as a model. Yet the extent to which the decree has the power where the decisions are taken more based on the interests of the ruler given the ownership of the resources.

The practice of natural resource management as illustrated in this article provides an overview of the vision of economic democracy. Starting from this point, the development of natural resource management based on people's economic democracy can be used as an alternative for the development of greater natural resources in Indonesia. Thus, the potential of existing natural resources can be managed from, by, and for the community. This should be the essence and vision of Indonesia's national development.

\section{References}

Arief, S. (2002). Ekonomi kerakyatan Indonesia mengenang Bung Hatta. Surakarta: Universitas Muhammadyah Surakarta.

Awang, S. A., Santosa, A., Indroyono, P., \& Wibowo. (2013). Pengembangan model inkubator ekonomi kerakyatan di Desa-desa miskin sekitar hutan: studi kasus di Kabupaten Gunung Kidul DIY. Yogyakarta: Pusat Studi Ekonomi Kerakyatan.

Baswir, R. (2005). Ekonomi kerakyatan: ekonomi rakyat dan koperasi sebagai Sokoguru Perekonomian. Paper presented at KEEP 2005. Yogyakarta: FE UGM.

Baswir, R. (2010). Manifesto ekonomi kerakyatan. Yogyakarta: Pustaka Pelajar.

Carnoy, M., \& Shearer, D. (1980). Economic democracy: the challenge of the 1980s. New York: M.E. Sharpe.

Damanik, J., Prihatin, S. D., \& Daryanti, S. (2014). Subjective life satisfaction in changing rural Yogyakarta, Indonesia, International Journal of Interdisciplinary Social and Community Studies, 12(3), 11-26.

Douglas, C.H. (1920). Economic democracy. New York: Harcourt, Brace, and Howe.

Gunungkidul map. (2017). Gunungkidul map. Retrieved November 24, 2017, from http:// www.gunungkidulkab.go.id/

Hamid, Edy S., Prapti, E. S., Hudiyanto, Mubyarto, \& Indroyono, P. (2003). Gerakan sendawar makmur di Kabupaten Kutai Barat: hidup dan berekonomi tanpa pemerintah. Jurnal Ekonomi dan Bisnis Indonesia (JEBI), 18(3), 205-217.

Hartzok, Alanna. (2002). Alaska model of governance: resource rents for public investment and citizen dividents. Geophilos, 2(1), 60-71.

Hatta, M. (2015). Membangun koperasi dan koperasi membangun. Jakarta: Penerbit Buku Kompas.

Mubyarto. (2002). Ekonomi pancasila: landasan pikir dan misi pendirian Pusat Studi Ekonomi 
Kerakyatan Universitas Gadjah Mada. Yogyakarta: BPFE.

Ostrom, E. (2009, December). Beyond markets and states: polycentric governance of complex economic systems. Paper presented at Workshop in Political and Policy Analysis, Indiana University, Bloomington, IN 47408, and Center for the Study of Institutional Diversity, Arizona State University, Tempe, AZ, USA.

Pusat Studi Ekonomi Kerakyatan (2009). Research Report: "Studi Penyusunan Rencana Aksi Daerah Penanggulangan Kemiskinan Kabupaten Penajam Paser Utara"
Ridley-Duff, Rory \& Bull, Mike (2011). Understanding social entreprise: theory and practice. London: Sage Publications.

Smith, J.W. (2000). Economic democracy: the political struggle of the $21^{\text {st }}$ Century. New York: M.E. Sharpe.

Susetiawan. (2010, December). Pembangunan dan kesejahteraan rakyat: ketidakmampuan para pihak melawan konstruksi neoliberalisme. Working Paper, Yogyakarta

Swasono, S. E. (1987). Membangun sistem ekonomi nasional: sistem ekonomi dan demokrasi ekonomi. Jakarta: UI-press. 